\section{Ethical Lingua}

Journal of Language Teaching and Literature

ISSN 2355-3448 (Print)

ISSN 2540-9190 (Online)

Volume 5, Number 2, August 2018 pp. $149-158$

\title{
Effectiveness of ABA Therapy for Children with Special Needs of Autism: A Study of Psycholinguistics View
}

\author{
Siti Ithriyah \\ siti_ithriyah@uhamka.ac.id / leemisuk251286@gmail.com \\ Universitas Muhammadiyah Prof. Dr. Hamka, Indonesia \\ URL : : http://journal.uncp.ac.id/index.php/ethicallingua/article/view/887 \\ DOI : https://doi.org/10.30605/ethicallingua.v5i2.887
}

Received : 31 December 2017; Accepted: 30 June 2018

\begin{abstract}
The background of this study is the recognition of an expert consultant psychiatrist named dr. Suzy Yusna SpKJ, who stated in our interview that based on the experience of practice before the 1990's the number of patients who were diagnosed as a child with autistic disorder in a year is only about five people. However, at this time of day can be diagnosed, three new patients. This shows a significant increase in autism. This study aims to describe (1) the effectiveness of Applied Behavioral Analysis (ABA) therapy model to increase autistic children's language; and (2) language development of children with autism after acquiring learning methods ABA therapy. This research method is descriptive research. The study takes its source data from children with special needs at Rumah Autis Bogor. Five children were selected as the research participants. We conclude that Lovaas' ABA method to prove the effectiveness of these therapies through phases and methods. Therapists who are experts in this field also helped determine the success in measuring the response level of language learning for children with autism. Thus, effective ABA therapy model applied in improving the language of children with autism. Before the ABA method is applied, the average child's ability to speak to one type of vocabulary requires learning four to five times (four and five days) with bad judgment and poor. However, after being given an action, then the average language skills of children with autism increased by only one or two lessons (one and two days) with the excellent score.
\end{abstract}

Keywords: applied behavioral analysis; autism; model therapy 
Siti Ithriyah:

Effectiveness of ABA Therapy for Children with Special Needs of Autism

\section{Introduction}

Language is one of the parameters in child development. Speech and language involve the cognitive, psycho-sensory, psychological, emotional, and environmental development of the child. Chaer (2003) says the production process or the process of language design is called encoding whereas the process of reception, recording and understanding is called the decode process. If the code can be interpreted as a signal or sign in the delivery of information; encoding means the event or process of the birth of the code and the decode means the event or process of receiving the code.

Alwasilah says the language is an utterance which means that the most important language medium is with any sounds perfect and the modern media of writing. According to him, we can speak without writing, but cannot write without speaking (at least to ourselves). In short, the writing system serves as a preserver of speech rather than regulating speech, therefore, language is called as a tool for the preservation of human culture. Normal children acquire language naturally and are able to follow language learning. However, some others for various reasons have difficulty in obtaining language and language learning. In fact, language is one of the most important aspects for human beings to be able to express themselves, socialize, obtain knowledge in education and used in communication with the environment.

Watson (1914) (in his book Behavior: An introduction to Comparative Psychology) says that language is a habit. Watson says that every child is capable of producing more vocabulary than a parrot: "For a long, the vocabulary of the "parrot stage", in the child may be fairly large consisting of as many as a hundred or more words". Humans can master the language natively only if the process is done between ages 2-12 years over 12 years people will not be able to master the language accent perfectly. From the facts that there is language is a biological phenomenon, especially on the development. The direction and appearance of an element in the language is a genetic problem. Kentjono (1990) states that language is an arbitrary system of symbolic sounds used by social group members to cooperate, communicate and identify.

The condition of the autistic person tends to be controlled by a self-centered or subjective mind or behavior. In addition, patients experience communication disorders and behavior is quite heavy. In fact, they are preoccupied with themselves and refuse to connect with others. These symptoms were originally considered lifelong abnormalities, but now autism in children can be corrected. Management of corrections should be made at the earliest possible age and should not exceed the age of five. Age 2-3 is the ideal age for correction because at that age the child's brain development is at the fastest stage. The average therapy takes 2-3 years to prepare the child to enter the regular school. 
Simmon and Lovaas (1969) in a journal titled Use of Pain and Punishment as Treatment Techniques with Child Schizophrenics, says about Lovaas' clinical analysis of the twin Pamela and twins who are autistic twins: "... the first two years she developed bizarre repetitive movement, hyperactivity and temper tantrums. Speech development was delayed and when it was established, consisted mainly of echolalia. The child was treated fairly intensively over a six-year period both as an outpatient and on an inpatient ... ". From the results of several months of research, Lovaas found progress in Pamela's speech. Pamela was originally a difficult child with autism, never playing eye contact and being content with herself. Lovaas began his research using stimulus on each exercise with Pamela, followed by Pamela's extremely disappointing response. Exercise after practice began to be used with reinforcement and Pamela was one of the students who could successfully attend school in a public school and successfully mingle with a child her age. The therapy in question is Applied Behavioral Analysis or ABA. The discoverer of this method is Dr. Ivar Lovaas (1927-2010). The basis of this method is to use a behavioral theory approach in the early intervention stage of autistic children who emphasize compliance, the skills to mimic and establishing eye contact. ABA therapy is used for ABK which includes many cases, including autism, attention-deficit / hyperactivity disorder (ADD / ADHD), Down syndrome, Asperger's syndrome, learning difficulties, speech delay, behavioral disorders, cerebral palsy, mental retardation, and so on. ABA therapy uses a "discrete trial" technique that all tasks on the target behavior are broken down into small steps. Discrete learning means detailing skills into small components, teaching to mastering, repetition, providing help, eliminating dependence, and giving praise (Lovaas, 2003).

Yuwono (2009) said in Indonesia, the issue of children with autistic disorders emerged around the 1990s. Autistic began to be widely known around the 2000s. Data on the number of children with autistic disorder is not known with certainty. However, the number of children with autistic disorders shows an increasingly striking increase. According to a consultant psychiatrist named dr. Suzy Yusna Dewi SpKJ, who is an expert in the field of handling emotional disorders in children and adolescents in Jakarta stated in our interview that based on his practice experience before the 1990s the number of patients diagnosed as children with autistic disorders within a year is only about five people. However, currently within a day can be diagnosed with three new patients. This shows a significant increase in autism. The purpose of this first study was to describe the effectiveness of the ABA model of therapy in improving the language of children with autism and the second language development of autistic children after obtaining ABA method learning therapy. 


\section{Method}

\section{Types of Research}

This research is descriptive research that analyzes data based on data obtained without adding and reducing it. The research with the descriptive method can provide the systematic, accurate and factual explanation of the data, properties, and relationships of the phenomena studied and ultimately produce a picture of scientific data.

\section{Data and Data Sources}

This research takes the data source from Rumah Autis Bogor. The location is an institution that moves for the development of children with special needs. The authors studied as many as five children with the consideration of time constraints because of language research autistic children undoubtedly different from normal children.

\section{Population and Sample}

The population in this study is the overall aspect and the number of students in the Rumah Autis in Jabodetabek. But a number of students of Rumah Autis in Bogor is 12 children. Thus, the authors assign $40 \%$ of the sample as an analysis of the total number of children in the Rumah Autis branch of five children. In this study, the authors determined the samples purposively by taking respondents intentionally from children with autism that many related to the purpose of research.

\section{Method of Collecting Data}

The instruments used for data collection are pre-test and post-test. Pre-test to find out the extent to which the subject matter to be taught has been known by the students and the post-test aims to find out whether all the important subject matter has been mastered well by the students. The researcher mainly use non-verbal tests due to the difficulty of communicating with children with Autism.

The method is Applied Behavior Analysis or it called ABA by Lovaas. Behavior analysis focuses on the principles that explain how learning takes place. Positive reinforcement is one such principle. When a behavior is followed by some sort of reward, the behavior is more likely to be repeated. Through decades of research, the field of behavior analysis has developed many techniques for increasing useful behaviors and reducing those that may cause harm or interfere with learning.

$A B A$ is the use of these techniques and principles to bring about meaningful and positive change in behavior. As mentioned, behavior analysts began working with young children with autism and related disorders in the 1960s. Early techniques often involved adults directing most of the instruction. Some 
allowed the child to take the lead. Since that time, a wide variety of ABA techniques have been developed for building useful skills in learners with autism - from toddlers through adulthood. The method used to collect data is the method refer. The method of providing this data is given the name of the method refer to because the way used to obtain data is done by listening to the use of language.

\section{ABA Techniques and Philosophy}

1. The instructor uses a variety of behavior analytic procedures, some of which are directed by the instructor and others initiated by the learner.

2. Parents and/or other family members and caregivers receive training so they can support learning and skill practice throughout the day.

3. The learner's day is structured to provide many opportunities - both planned and naturally occurring - to acquire and practice skills in both structured and unstructured situations.

4. The learner receives an abundance of positive reinforcement for demonstrating useful skills and socially appropriate behaviors. The emphasis is on positive social interactions and enjoyable learning.

5. The learner receives no reinforcement for behaviors that pose harm or prevent learning.

These techniques can be used in structured situations such as a classroom lesson as well as in "everyday" situations such as family dinnertime or the neighborhood playground. Some ABA therapy sessions involve one-on-one interaction between the behavior analyst and the participant. Group instruction can likewise prove useful.

\section{Results}

The main finding of this study is the number of children with autism who have difficulty communicating and learning the language, especially those who commit errors in mentioning an object without seeing the image visually. Once the ABA method applied, changes occur during the test with only one action child with autism can follow the requested word correctly. This is said to be effective because the sample used as many as five people from a total of twelve people who study at Rumah Autis Bogor.

The results showed that therapy using ABA method is more effective in handling the behavior of children with autism. The grading form consists of five levels: Excellent for a one-time therapist, good for therapists twice, average for therapist three times, poor for therapist four times, and bad for therapist five times. This can be known as in tables 1, 2, 3, 4 and 5 which are the results of tests of five children with autism. 
Siti Ithriyah:

Effectiveness of ABA Therapy for Children with Special Needs of Autism

Table 1. Subject 1: Salwa



Table 2. Subject 2: Maulidya

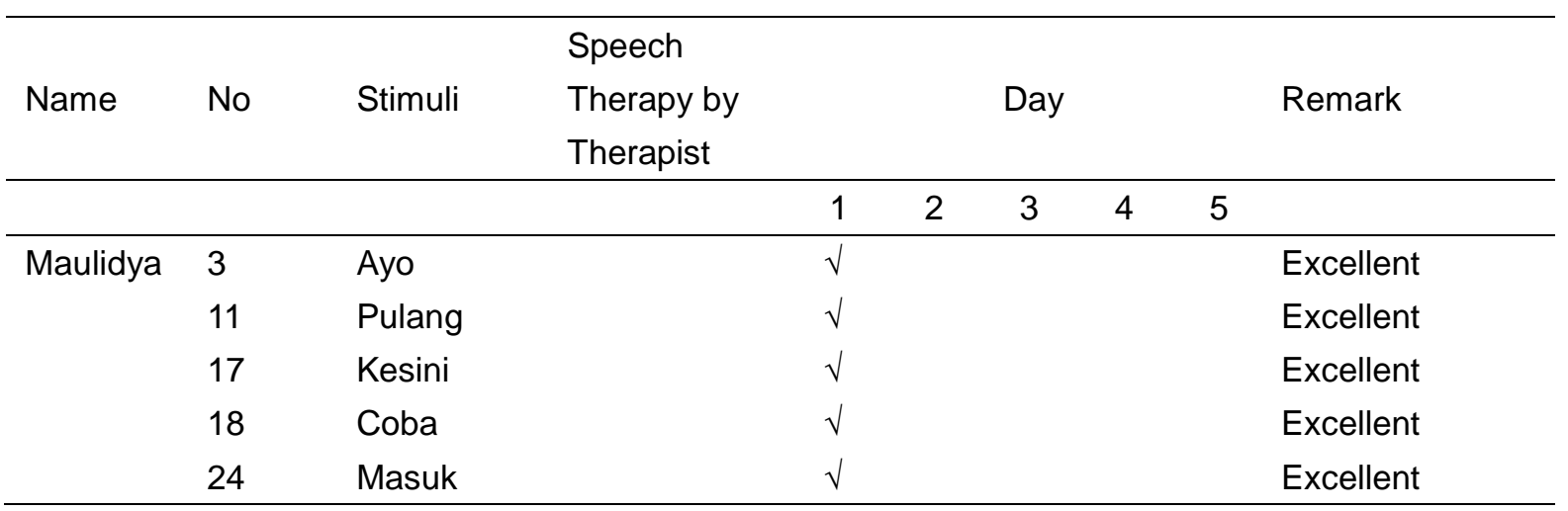

Table 3. Subject 3: Fariz

\begin{tabular}{lllllllll}
\hline Name & No & Stimuli & $\begin{array}{l}\text { Speech } \\
\text { Therapy by } \\
\text { Therapist }\end{array}$ & & & Day & & Remark \\
\hline Fariz & 3 & Jalan & & 1 & 2 & 3 & 4 & 5 \\
& 4 & Lurus & & $\sqrt{ }$ & & & & Excellent \\
& 13 & Buang & & $\sqrt{ }$ & & & & Excellent \\
& 23 & Ambil & & $\sqrt{ }$ & & & Excellent \\
& & & & & & Excellent \\
\hline
\end{tabular}


Table 4. Subject 4: Septian

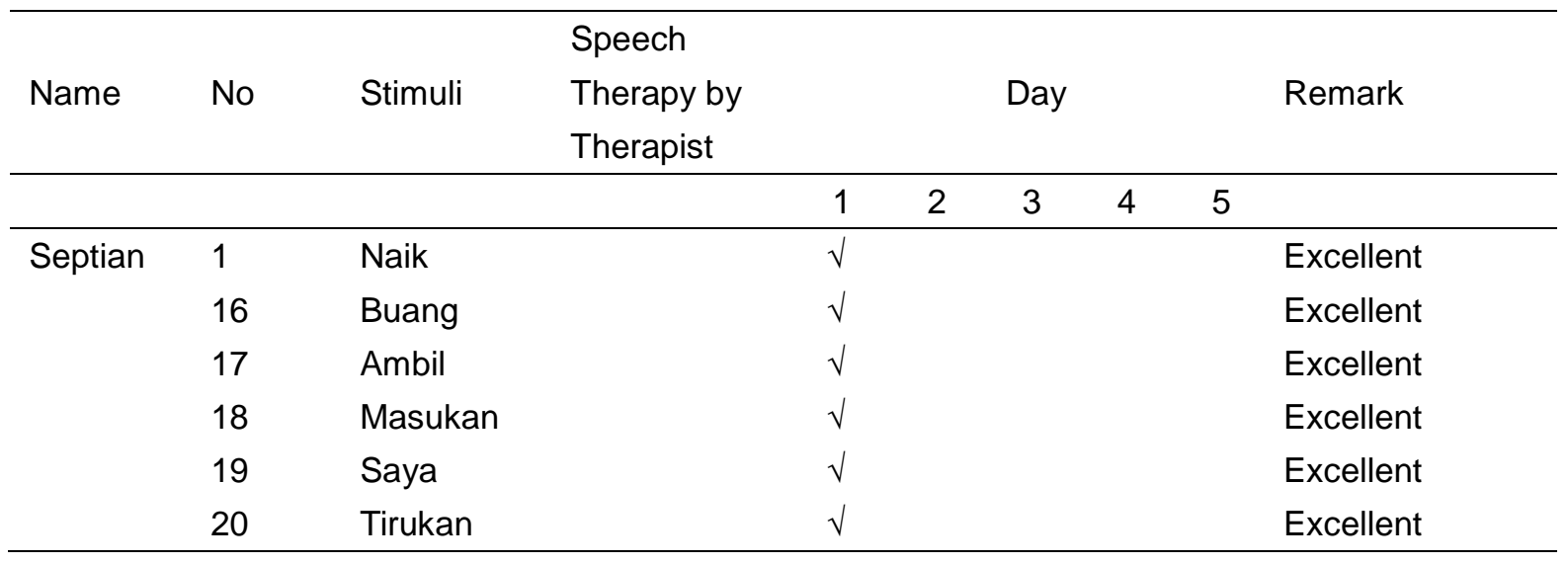

Table 5. Subject 5: Alif

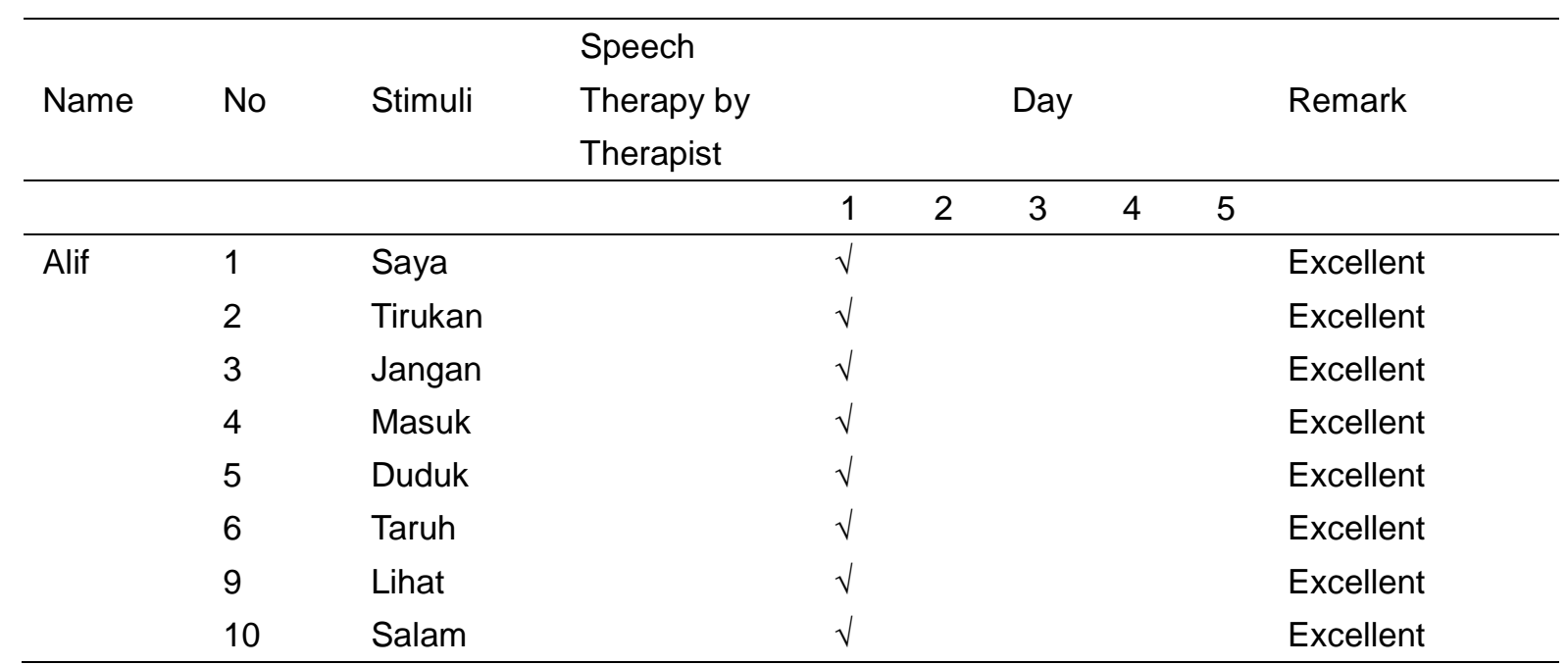

\section{Discussion}

This study shows the effectiveness of the ABA method can be known through a positive response on the first day of the test and only repeated once by the therapist. Positive responses are obtained after several weeks of meetings whose level of learning is tailored to the child's condition. Based on the results of observations made by the authors of the therapist's actions in dealing with children with autism, then presented data about the stimulus and response of autistic children in response to the stimulus. Based on the stimulus given to children with autism using the ABA method and the duration of time set for autistic children to understand the stimulus obtained a picture that any stimulus provided by the therapist and responded by the autistic child is assessed the form of appreciation for the progress of acquisition of the language. 
Siti Ithriyah:

Effectiveness of ABA Therapy for Children with Special Needs of Autism

Chaucard (1983) states that every child must form language on the basis of the possibilities of his motor neuron power; he must form for himself the language that has been provided by the community around him. By learning to speak he learns his original thinking and awareness that darkness opens and becomes a human consciousness. There are now so many investigations that it is possible to know the age levels for language learning. The development is a little but continues to advance with no shaping baby born into the language. This language starts from the age of 3 years and gradually becomes perfect in the following years. The study and development of the abstraction and thinking skills are precisely the perfections of the language, which is then followed by the writing. Conversation implies mastery of childhood sensory-motorists must be able to recognize the sounds he hears; it must be able to control all of the complex uric reactions that allow the pronunciation of sounds as desired. Then writing will cause the same problem for the vision of reading time and motor control of the hand.

Therefore, it is not surprising that language progress is related to sensory-motor development. Shah (2010) says an operant is some behaviors or responses that bring about the same effect on the immediate environment. Unlike in respondent conditioning (the response is brought about by a certain stimulus), the response in operant conditioning occurs without preceded by the stimulus but by the effect it generates by the reinforcer. Reinforcer itself is the stimulus that raises the possibility of a certain number of responses but is not accidentally held as a couple of other stimuli as in classical respondent conditioning.

Mar'at (2009) says in Applied Developmental Psycholinguistics applied linguistics there is a section called Abnormal Applied Developmental Psycholinguistic. It discusses what is done to help children who are experiencing delays in language development due to a congenital abnormality in their articulation devices or by emotional factors and other causes. Experts argue that in the face of children who have developmental disorders, must adapt to the style of communication and interaction. The authors' that in addition to the use of verbal language, there are many other ways as a stimulus to communicate, namely: (1) Using facial expressions. (2) Using gestures or gestures. (3) Change the tone of voice. (4) Pointing the image. (5) Referring to writing. (6) Using the communication board. (7) Using symbols. These methods can not only be used independently but can also be combined to form a "stronger" message. Most people with ASDs are visual learners, meaning it's easier to process visible information than just heard. Mulyadi (2011) says people with autism also tend to have unstable emotions. For example, easy to angry, easy fear that sometimes does not make sense, very taste can laugh laughing for the ordinary and others. It is said that there is a problem on the part of the brain that regulates the emotion of the limbic system. As a result, all things related to the child's emotional control seem less optimal. Dorland (2002) in Medical Dictionary states the limbic system 
is a term for brain structures common to all mammals that are then linked to more important life in other activities such as autonomic function and certain aspects of emotions and behaviors including their language behavior. Emotionality in Kartono (2011) is the size of sensitivity to feelings or renjana. Emotion is the vibration of the soul, the novelty, the renjana. The more optimistic people are loaded with eukoloi feelings. He tends to see all the experience in terms of beautiful and fun. In contrast, individuals with dyskoloi tend to see events with grief, displeasure, anxiety or fear and pessimism.

Shichida (2003) says the right brain is an intuitive brain that has an inner power capable of accepting information as a cosmic vibration. The right brain is a mystical brain whose power exceeds the boundaries of space and time. However, it is a pity that any manifestation that occurs when the right brain is inadvertently activated is viewed with one eye and suspected of being a "disease" and is considered strange or abnormal to be rejected. In autistic children handling, the ABA learning model provides several advantages such as the way the therapy is given from the easy to the most difficult to gradual training and will not move to the next stage before a child can master. Another advantage is the ABA method uses a therapy tool that is efficient enough to support the success of therapy. ABA model aids such as picture/numbers cards, beam boards, and everything related to a person's visuals remember an autistic person is quicker at what they see than they hear. ABA authors' technique of autistic children should base their teaching processes on the provision of stimuli (instructions), individual responses (behaviors) and consequences (due to behavior). When implementing this technique, the therapist must be consistent in providing the stimulus, response and consequence provided. In addition, there is also a need for adequate knowledge of autism and ABA techniques.

\section{Conclusion}

The authors' conclude that in children handling children especially for autistic children there is a proper method of therapy. The ABA method found by Lovaas proves its effectiveness through the therapies and stages of the method. Therapists who are experts in this field also determine success in measuring the response rate of language learning for children with autism. Thus, the ABA model of therapy is effectively applied in improving the language of children with autism in the Rumah Autis of Bogor. Children with autism have an average language development after learning ABA method learning. Before the ABA method was applied, the average language ability of a child for one type of vocabulary requires four to five lessons (four and five days) with poor and poor assessments. However, once given the action, then the average language ability of children with autism increases with only one or two lessons (one and two days) with an excellent assessment. Presumably, his research can contribute to add insight into 
the meaning and linguistic vocabulary that is typical for linguistics especially in applied linguistics. Therefore, criticism and suggestions are needed for the refinement of this research. It is important that some suggestions may be examined the language of children with autism by the comparative study by comparing the results between handling autistic children who treated using methods Lovaas with other methods.

\section{Acknowledgement}

This paper is a full report of research results on the effectiveness of learning methods in children with special needs with autism characteristics. In the implementation of this study the authors get much help from individuals and institutions or institutions both private and government. Therefore, on this occasion the author would like to convey the greatest gratitude to the related institutions and friends who have provided guidance and direction guidance from the beginning until the end of this research.

\section{References}

Chaer, A. (2003). Psikolinguistik (Kajian Teoritik). Jakarta: PT Rineka Cipta.

Chauchard, P. (1983). Bahasa dan Pikiran. Translated by A. Widyamartaya. 1983. Yogyakarta: Yayasan Kanisius.

Dorland. (2002). Kamus Kedokteran Edisi 29. Philadelphia, Pennsylvania: W. B. Saunders Company.

Kartono, K (2011). Patologi Sosial: Gangguan-gangguan Kejiwaan. Jakarta: PT Raja Grafindo Persada.

Kentjono, D. (1990). Dasar-Dasar Linguistik Umum. Fakultas Sastra Universitas Indonesia.

Lovaas, O.I. (2003). Teaching Individuals with Developmental Delays: Basic Intervention Techniques. Austin. Texas: pro-Ed, Inc.

Mar'at, S. (2009). Psikolinguistik: Suatu Pengantar. Bandung: PT Refika Aditama.

Mulyadi, K. (2011). Autism is Treatable : Tiga Pekan Menuju Keberhasilan Terapi. Jakarta: PT Gramedia.

Shichida, M. (2003). The Mystery of The Right Brain: Mengungkap Misteri Otak Kanan untuk Membuat Anak Jadi Genius. IKAPI Jakarta: PT Elex Media Komputindo.

Simon, J., Lovaas, O.I. (1969). Use of Pain and Punishment as Treatment Techniques with Child Schizophrenics. A Journal from www.neurodiversity.com. Los Angeles, California.

Syah, M. (2010). Psikologi Belajar. Jakarta: Rajawali Pers.

Watson, J. B. (1914). Behavior: An introduction to Comparative Psychology. New York: Henry Holt and Company.

Yuwono, J. (2009). Memahami Anak Autistik (Kajian Teoritik dan Empirik). Bandung: Alfabeta. 